\title{
16
}

\section{Timely help or icing the cake? Revisiting the effect of public subsidies on private R\&D investment in Taiwan}

\section{Hsini Huang and Nailing Kuo}

\section{Introduction}

Ever since Solow's (1957) pioneering work, it has been widely acknowledged that research and development $(\mathrm{R} \& \mathrm{D})$ and technological innovation are key drivers of economic growth and national competitiveness (Coe and Helpman 1995). However, it is also commonly agreed that the market will fail to invest sufficiently in R\&D if it creates non-rival and non-excludable outcomes - that is, if the outcomes are 'public goods'. Private firms are afraid of having limited capacity to capture the returns from their R\&D activities. As a result, the allocation of financial resources to R\&D is likely to be at a suboptimal level, as $\mathrm{R} \& \mathrm{D}$ can yield positive spillover effects to the relevant industry or even to society more broadly. Scholars argue that, in addition to direct public R\&D where spillover effects are greatest (e.g. from 'basic' research), governments should use various policy tools to provide incentives for firms to expand their R\&D spending-for example, strengthening the

1 The authors acknowledge valuable comments from Professor Andrew Podger, Tsai-tsu Su and the anonymous reviewers who helped to shape this chapter. In addition, we are thankful to our graduate students Tzu-Hao Chen and Wei-Jie Liao for their assistance with the collection of these data. 
intellectual property system, providing direct financial support to conduct $\mathrm{R} \& \mathrm{D}$ projects, offering $\mathrm{R} \& \mathrm{D}$ tax credits (Hall and Van Reenen 2000), providing public venture capital (Lerner and Hall 2010) and government $\mathrm{R} \& \mathrm{D}$ grants or providing government loans with low interest rates.

Over the past three decades, as a latecomer in the global economy, Taiwan has performed well in manufacturing production and technological development, especially in the precision instrument and electronics industries. Figure 16.1 shows an international comparison of the gross domestic spending on R\&D of Taiwan with a selection of Organisation for Economic Co-operation and Development (OECD) countries, illustrating that Taiwan, as a small-scale economy, ranks high in terms of nationwide $\mathrm{R} \& \mathrm{D}$ expenditure as a share of gross domestic product (GDP) (a simple measure of R\&D intensity for a country). According to the OECD's Frascati Manual, the measure of $\mathrm{R} \& \mathrm{D}$ expenditure 'consists of the total expenditure (current and capital) on R\&D carried out by all resident companies, research institutes, university and government laboratories' (OECD 2015). For more balanced international comparison, government tax incentives are not included in the calculation of $R \& D$ expenditure.

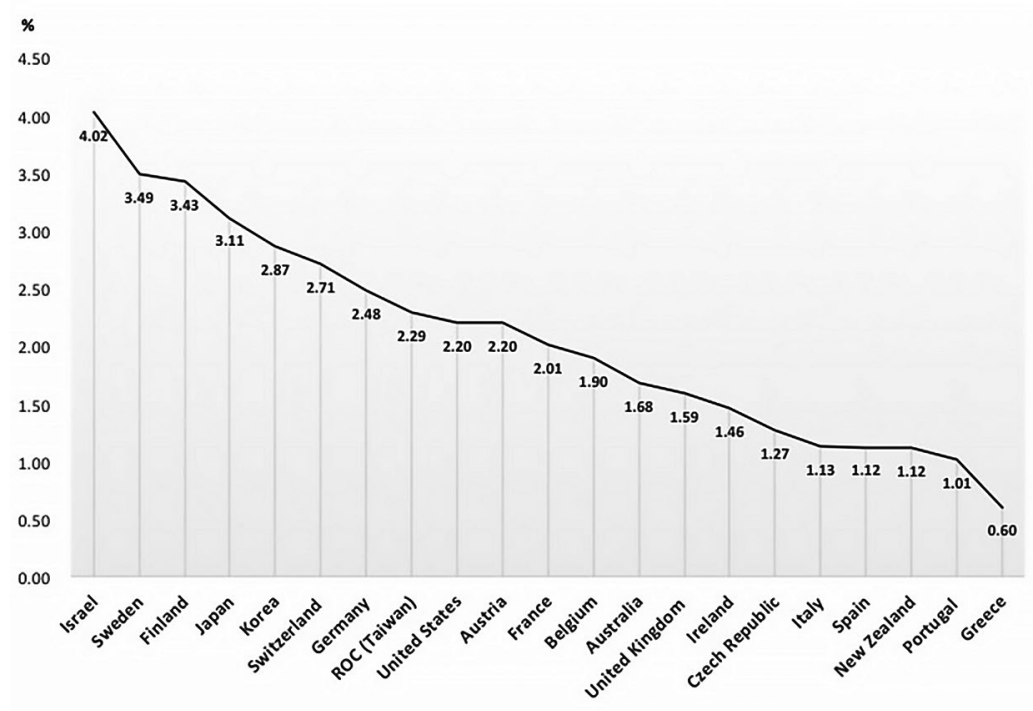

Figure 16.1 Comparison of civil R\&D expenditure as a percentage of national GDP across Taiwan and OECD countries: A 1996-2012 average Note: Civil R\&D expenditure refers to all but national defence-related R\&D investments and tax expenditure by business, government, higher education and non-profit organisations. Sources: Ministry of Science \& Technology and Taiwan Institute of Economic Research (2006, 2014). 
Studies of developing countries are, however, scarce. A survey of relevant empirical studies conducted by Zúniga-Vicente et al. (2014) found that, of all the surveyed papers published between the mid-1960s and 2011, approximately 40 per cent of the studies of $R \& D$ investment used data from the United States, while the rest drew from data for the European Union or other developed countries, such as Ireland, Australia and Japan. Few studies of the effects of policy schemes created by the public sector on private $\mathrm{R} \& \mathrm{D}$ use data from developing or newly industrialised countries, such as Taiwan (Yang et al. 2012). Meanwhile, a large academic literature has investigated whether the provision of $\mathrm{R} \& \mathrm{D}$ tax incentives promotes $\mathrm{R} \& \mathrm{D}$ in firms and, to a lesser extent, explores the effects of other policy schemes (e.g. government grants) on inducing private firms' expenditure on $\mathrm{R} \& \mathrm{D}$.

As an export-oriented country, Taiwan is one of the best-performing economies among the developing countries who specialise in the electronics and precision machinery industries. Figure 16.2 depicts Taiwan's R\&D/ GDP ratio during the period $1996-2013$ as a simple measure of the knowledge intensity in the economy and the amount of government $\mathrm{R} \& \mathrm{D}$ funding used to support business enterprise $\mathrm{R} \& \mathrm{D}$ expenditure. For the two measures plotted in Figure 16.2, tax expenditure (i.e. tax relief) is separate from the measurement. The R\&D/GDP ratio increased steadily from 1.8 per cent in 1996 to 2.28 per cent in 2001, followed by a slight downward trend between 2002 and 2006, reflecting the global economic recession in 2000 and 2001. It then gradually increased from 2007 and reached 2.9 per cent in 2013. The amount of government funds used to support private $\mathrm{R} \& \mathrm{D}$ expenditure has increased rapidly since 2002, reaching NT\$4.7 billion (A $\$ 198$ million) in 2004 and climbing again after 2007, with a second spike, of NT $\$ 6.4$ billion (A $\$ 270$ million) in 2010, after the old industrial technology policy, the Statute for Upgrading Industries (SUI), was annulled, in May 2010. The new Statute for Industrial Innovation (SII) reduces the tax relief for conducting R\&D, lowers corporate tax and provides more diverse financial support, including direct and indirect subsidies, such as R\&D grants, innovation grants, national development fund support and venture capital investment for start-ups. The Taiwanese Government has emphasised subsidising firms for their $\mathrm{R} \& \mathrm{D}$ hiring, $\mathrm{R} \& \mathrm{D}$ projects and product commercialisation based on applications for grants, and so on. Figure 16.2 also illustrates that the amount of funds on offer to private enterprise for conducting R\&D activities declined after 2010. Some observers suggest that, due to the burden of low corporate tax following the change of the SII, the total government budget has decreased in response. 


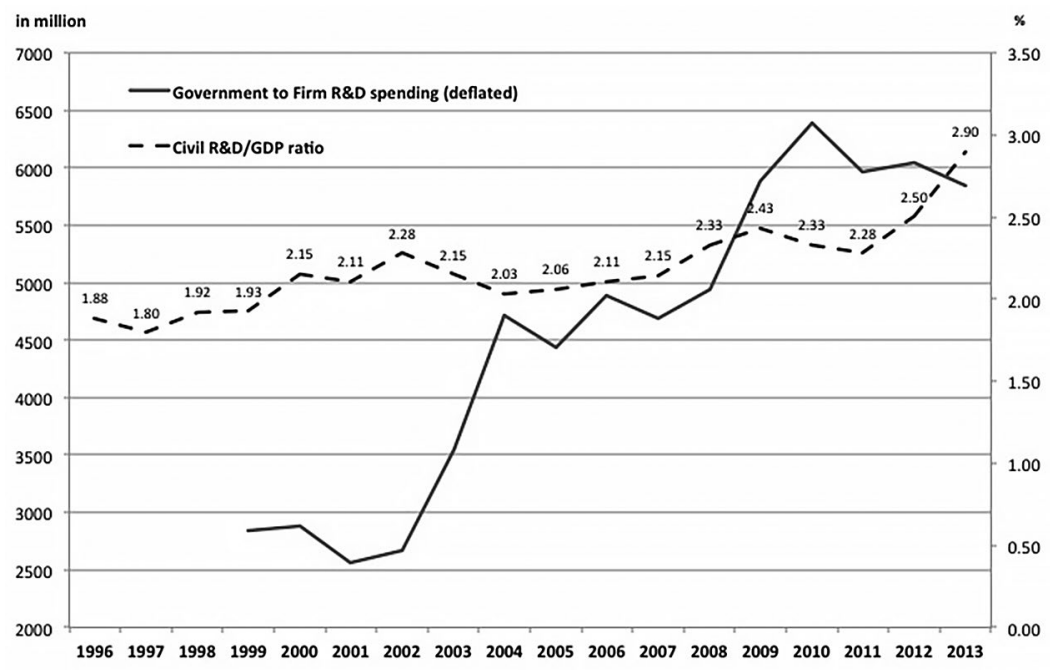

Figure 16.2 Taiwan's civil R\&D/GDP ratio and government R\&D spending to private firms, by year, 1996-2013

Sources: Ministry of Science \& Technology and Taiwan Institute of Economic Research (2007-14).

By looking at public innovation support (not including tax expenditure) relative to private R\&D expenditure (see Figure 16.3), the data show that the ratio fluctuated over the period 1999-2014, with a maximum of 2.5 per cent recorded in 2004. After that peak, public innovation support relative to private $\mathrm{R} \& \mathrm{D}$ expenditure gradually declined, to 2.0 per cent in 2008, and continued downwards, to 1.5 per cent in 2014. Overall, since 2004, we see a general downward trend in government R\&D support as a percentage of private $R \& D$ investment. The descriptive results from Figures 16.2 and 16.3 suggest that public support for private $R \& D$ expenditure is not a level trend but has varied over time.

Drawing on these data of changes in public $R \& D$ support over the past 15 years, our research examines whether the input of public grants or support for $\mathrm{R} \& \mathrm{D}$ invokes companies's subsequent $\mathrm{R} \& \mathrm{D}$ expenditure in Taiwan. The findings of this research contribute to discussion about the direct effect of government subsidies on private firms' $R \& D$ investment. The more we know about the impacts of public subsidisation, the more likely it is we can improve the effectiveness of and value for government money. Additionally, given the existence of sectoral differences, this chapter will further investigate the effects of public subsidies on the inducement of private $\mathrm{R} \& \mathrm{D}$ across different industries. 


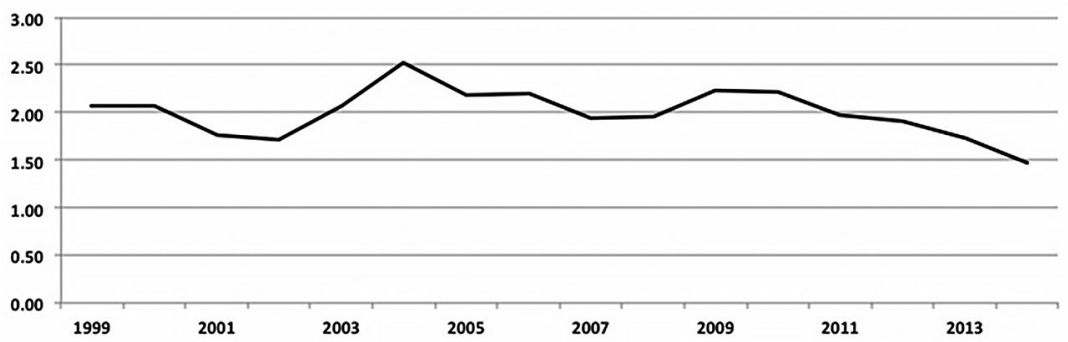

Figure 16.3 Public R\&D support to the private sector as a percentage of private R\&D expenditure in Taiwan, 1999-2014

Sources: Ministry of Science \& Technology and Taiwan Institute of Economic Research (2007-14).

The chapter is structured as follows. The next section provides a brief review of the literature about the effects of government intervention on $R \& D$ activities. Section three describes the method and data used for analyses. The results are presented in section four and the chapter concludes with discussions of our findings and potential avenues for future research.

\section{Literature review}

\section{Public support for private R\&D}

Two policy tools have commonly been applied to stimulate industrial R\&D: tax incentives and direct government financial support. There have been many studies on the relationship between tax incentives and industrial $\mathrm{R} \& \mathrm{D}$. Tax incentives for $\mathrm{R} \& \mathrm{D}$ have long been identified as a suboptimal remedy for failures in the market (Hall and Van Reenen 2000). Tax incentives - the major policy instrument used to encourage the supply of R\&D activities in the past two decades - have been receiving criticism in Taiwan. According to Yang et al. (2012), one big criticism of $\mathrm{R} \& \mathrm{D}$ tax credits is lack of fairness - that is, the system essentially favours large enterprises and specific industries instead of small and medium-sized firms. Moreover, large companies are more likely to claim substantial expenses even for costs of questionable relevance to genuine R\&D activities (Bozeman and Link 1985). Figure 16.4 shows that the amount of tax expenditure grew steadily from 1993 to reach a peak in 2007 of about NT $\$ 200$ million (A $\$ 8.4$ million). During this period and through to 2010, the SUI was the most important industrial technology policy. The main tool for increasing industrial upgrading under the statute 
was the provision of tax relief for $R \& D$ activities, $R \& D$-related personal training, automation, pollution control and investment in risky areas. As Figure 16.4 illustrates, the amount of tax credit for R\&D has been increasing rapidly since 2004, raising concerns from stakeholders about the excessive use of tax incentives.

To address concerns about the effectiveness and fairness of the R\&D tax incentive policies, in December 2009, the SUI was replaced with a new policy, the SII. This reduces the credit rate of R\&D spending to 15 per cent from the effective rate of 30 per cent, annuls the incremental credit rate (up to 50 per cent) for the excess of current-year R\&D spending amounts over the average of the preceding two years' $R \& D$ spending amount and limits the use of credit to only the current year's income tax payable (disallowing any unused credit to be carried forward to subsequent years). Together, these changes have caused a sharp fall in tax reductions for $\mathrm{R} \& \mathrm{D}$, as shown in Figure 16.4.

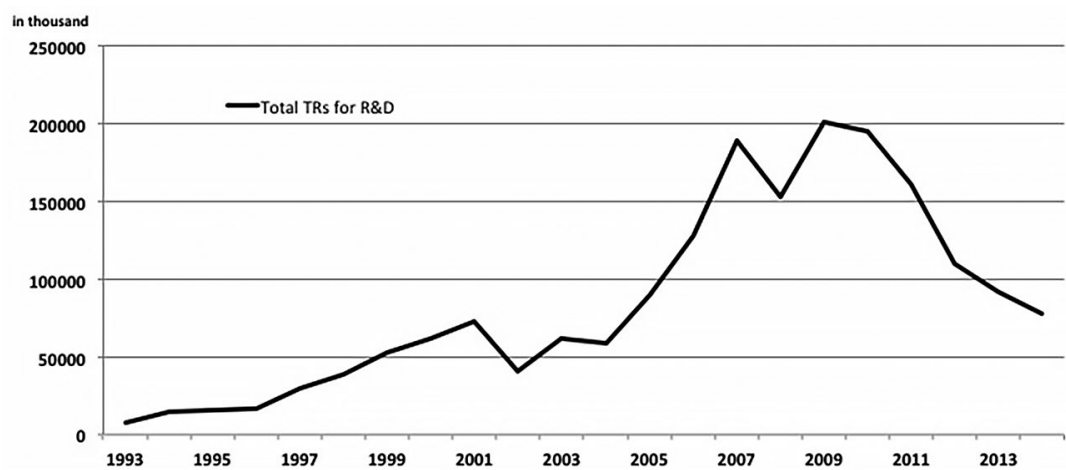

Figure 16.4 Total tax reductions for R\&D in Taiwan, 1993-2014

Note: Dollar values are in 2011 dollars using the consumer price index (CPI) reported by the Directorate-General of Budget, Accounting and Statistics of the Executive Yuan, Taiwan.

Source: Department of Statistics (various years).

While the reduced emphasis on tax expenditure was informed by research that questioned the impact of tax credits, the impact of direct public R\&D subsidies (e.g. grants, public loans, venture capital investment or contracts) on private $\mathrm{R} \& \mathrm{D}$ has so far received less attention, despite the scale of public expenditure. Proponents such as Girma et al. (2008) argue that public R\&D subsidies induce employment creation and increase wages. There are doubts, however, about whether subsidisation policy does spur innovation (Wallsten 2000; Czarnitzki and Fier 2002). For instance, 
Wallsten (2000) questioned the optimistic view that says the government will be able to rectify market failure, suggesting that the government is also picking the winners. In this regard, the evidence is mixed. As with the criticisms of tax credits, politicians or industrial interest groups could improperly use government subsidies to reward their own interests.

Mansfield (1986) was a pioneering scholar who distinguished between the social return and private return of money invested in R\&D. His findings demonstrated that the social benefits-both measurable and intangibleof industrial innovation were significantly larger than private benefits, which usually refer merely to tangible benefits that can be measured in terms of monetary values. Put differently, public support for private R\&D is seen to enlarge social welfare in addition to the money or tax deduction received by companies. However, as Bozeman and Link (1985: 377) suggest, the fundamental question is 'how much social value is enough to warrant public support?'. This remains an open issue given the mixed results of research to date. The following section summarises the two major arguments regarding the net effect of government support for $R \& D$, the complementary effect and the substitution effect.

\section{The net effect of government support for $R \& D$}

A large number of empirical studies across the world have tried to answer the question of whether public $R \& D$ subsidies and privately financed $\mathrm{R} \& \mathrm{D}$ are substitutes or whether they complement each other (David et al. 2000).

For the substitute (or crowding-out) effect, using data on Israeli manufacturing firms, Lach's (2002) study shows that government funding is actually replacing private firms' $R \& D$ investment. Assuming private firms aim to maximise profits, the crowding-out effect is expected to occur when applying for a grant is cheap and the probability of getting the funding is high compared with private firms' alternative financing sources, such as applying for bank loans (Aschhoff 2009). Empirically, Wallsten (2000) found crowding-out effects using a sample of Small Business Innovation Research (SBIR) program awardees in the United States and the tendency to pick previous winners to assure program success. Despite the almost dollar-to-dollar crowding-out effect of awards, Wallsten also argued that the direct support from the SBIR had some positive effect by keeping the award-receiving firms' $R \& D$ activities at a constant level. 
Another thread of the international literature supports the positive effect of government funding for R\&D, suggesting that public support reduces risks for private firms and induces them to invest more in $R \& D$. Moreover, public financial support addresses the externality problem that the original investor in the new technology is not able to capture the full returns (Lerner and Hall 2010). Public funding is viewed as a way to mitigate market failure and may increase incentives for the private sector to invest in $\mathrm{R} \& \mathrm{D}$ (Arrow 1962). Conventional wisdom suggests projects with high rates of return are those with higher risk. But, as Aschhoff (2009) noted, riskier private $R \& D$ projects often benefit more from the assistance of government subsidies. Compared with private venture capital or investment organisations, a government agency with a group of relevant experts may be better able to identify the most risky but promising projects among all the applicants for funding (Lerner 1999). This may suggest that, when the $\mathrm{R} \& \mathrm{D}$ project has high risk, government support is likely to stimulate additional investment (measured as $R \& D$ expenditure) by the private sector.

Possible mechanisms driving the additionality effect may be complex. For instance, government funding (i.e. subsidy) can provide a good signal for firms to acquire external private funding (Meuleman and De Maeseneire 2012). Obtaining a government grant may indicate to banks or other external private financial institutions that the investment is worthwhile. In Görg and Strobl's (2007) study, the amount granted also affects the impact of the R\&D. They found that the additionality effect occurs when firms receive small grants, while large grants could serve to decrease private R\&D spending. Using Spanish data for manufacturing firms, González and Pazó (2008) found the additionality effect of public funds on private $R \& D$ investment was relatively weak for those firms that would conduct R\&D in the absence of government support. Various studies have provided some evidence to support this conclusion, including in the case of $\mathrm{R} \& \mathrm{D}$ investment by German manufacturing firms (Almus and Czarnitzki 2003), German service companies (Czarnitzki and Fier 2002) and Spanish manufacturing firms (González and Pazó 2008).

In practice, the effects of public subsidies on private $R \& D$ expenditure can be subtle. Aschhoff (2009) summarised four kinds of possible effects of direct public funding on a firm's R\&D expenditure: full crowdingout, partial crowding-out, additionality and no effect (see Figure 16.5). In the case of full crowding-out, private $\mathrm{R} \& \mathrm{D}$ expenditure is expected to be lower than the full amount of public funding supplied. The partial crowding-out situation is slightly better than the full crowding-out story, 
with some net increase in total (public and private) $R \& D$ expenditure. Additionality is exhibited when firm-financed $R \& D$ investments increase when they receive public subsidies. The fourth type of effect is no effect, which suggests that the amount of privately financed $R \& D$ expenditure remains the same regardless of receipt of government subsidies.

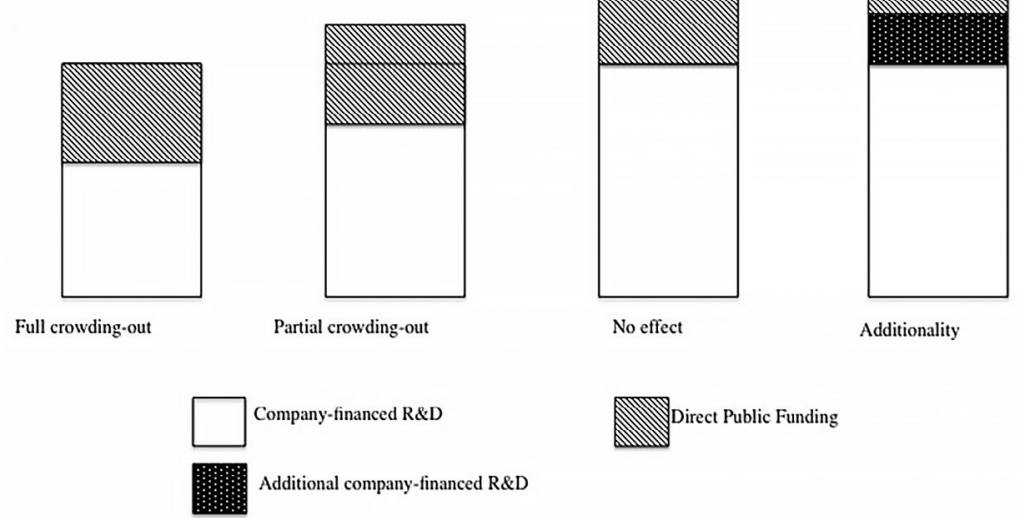

Figure 16.5 Possible effects of public R\&D funding on firms' $R \& D$ expenditure

Source: Authors' illustration based on concepts in Aschhoff (2009).

The effect on private $R \& D$ investment of public support could vary due to firm heterogeneity. Wallsten (2000) evaluated payments through the SBIR program and found they have no impact on young R\&D-intensive firms. Toivanen and Niininen (2000) observed some substitution effect in the case of subsidies to large firms, while, for small firms, the public funding had no effect on privately financed $R \& D$, indicating that the scale of financial and industrial resources is likely to change firms' strategies for R\&D spending. In contrast, using panel data for Israeli firms, Lach (2002) reveals a significant increase in private $R \& D$ spending for small and medium-sized firms, but no effect in large firms.

Summarising the above literature, existing evidence on the direct effect of government subsidies is mixed, although there has been an increase in empirical studies using advanced econometrics models to examine this issue. Moreover, scholars also warn that empirical methods with which to investigate this topic should control for selection and endogeneity bias in the samples. For example, studies should account for industrial heterogeneity, as firms in different sectors do not participate in $R \& D$ 
equally (Blanes and Busom 2004). The contribution of this chapter is to continue this discussion along the same theoretical thread to test whether the effect of public subsidies is a story of crowding-out or one of additionality across industries at different levels of technological intensity.

\section{Data, method and results: An exploratory analysis of the effects of government $R \& D$ funding}

The data used here are mostly extracted from the indicators of the science and technology sectors compiled by Taiwan's Ministry of Science and Technology. The information collected corresponds to the sectoral level, suggesting this as the unit of analysis. The dataset consists of an unbalanced panel of all 24 sectors $^{2}$ during the period 2001-13 in Taiwan, including five high-technology sectors, five medium- to high-technology sectors, six medium-low-technology sectors and eight low-technology sectors based on the industrial classification ${ }^{3}$ defined by the OECD's Frascati Manual in 2002. To measure the causality between government funding and private firms' R\&D investment, information about lagged variables is important for determining the persistence of innovation activities. As a result, we construct a panel sample of 304 observations from 24 industries.

Many empirical studies have shown that most private $\mathrm{R} \& \mathrm{D}$ projects are financed internally (Hall 1992; Hao and Jaffe 1993; Brown et al. 2009). This is also true for private companies conducting $R \& D$ research in Taiwan. Figure 16.6 illustrates the percentage of private $R \& D$ expenditure funded by government, which is actually very low, yet the proportion of government support is observed to be higher in medium- to hightechnology sectors $($ mean $=2.7$ per cent) than in the high-technology sectors $($ mean $=1$ per cent $)$.

2 The aircraft and spacecraft sector is the only high-technology sector that covers data only from 2001 to 2006. The other 23 sectors have data for the whole period, from 2001 to 2013.

3 The five high-technology sectors are: pharmaceuticals; office, accounting and computing machinery; radio, TV and communications equipment and apparatus; medical, precision and optical instruments, watches, clocks and related instruments; and aircraft and spacecraft. The five medium- to high-technology sectors are: chemicals and chemical products; machinery and equipment; electrical machinery and apparatus; motor vehicles, trailers and semi-trailers; and transport equipment. The rest are either low-medium or low-technology industries, such as rubber and plastic products, basic metals, food products and beverages and recycling. 


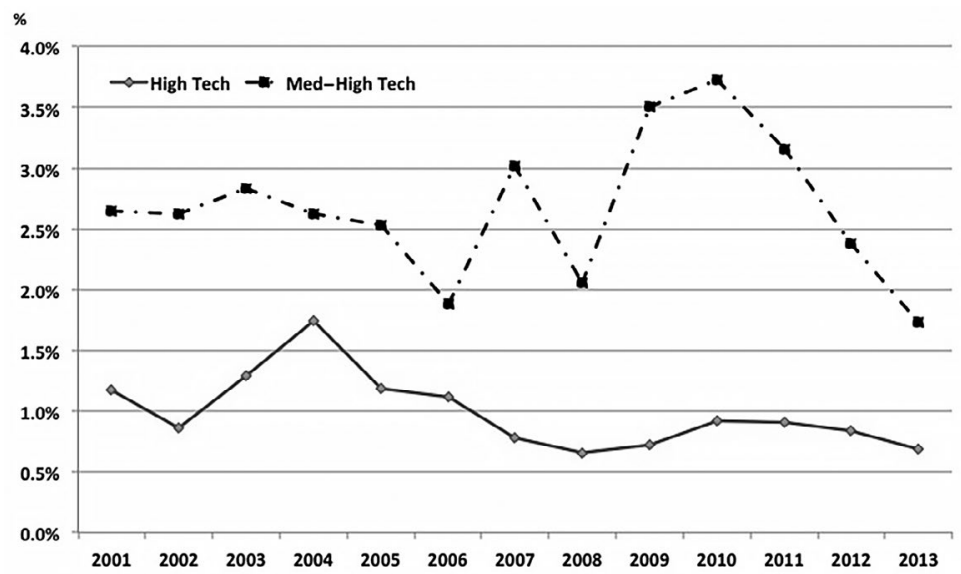

Figure 16.6 Enterprise R\&D funded by the Taiwanese Government, 2001-13 (per cent)

Sources: Ministry of Science \& Technology and Taiwan Institute of Economic Research (2006, 2014).

Granger causality models are applied to explore the relationship between government R\&D funding and private R\&D spending. According to Granger (1988), the independent variable ' $\mathrm{X}$ ' can be used as a Granger cause of the dependent variable ' $Y$ ' if it satisfies the following two principles: '(a) The cause occurs before the effect and (b) the causal series contains special information about the series being causal that is not available in the other available series' (Granger 1988: 200; Stock and Watson 2011). We use Equations 16.1 and 16.2 as examples.

Equation 16.1

$Y_{t}=f\left(Y_{t-1}, \ldots, Y_{t-n-1}, X_{t-1}, \ldots, X_{t-n-1}\right)$

\section{Equation 16.2}

$X_{t}=f\left(X_{t-1}, \ldots, X_{t-n-1}, Y_{t-1}, \ldots, Y_{t-n-1}\right)$

' $\mathrm{X}$ ' is considered to be a Granger cause of ' $\mathrm{Y}$ ' if the following two rules are true. In Equation 16.1, the joint test of the lag of ' $\mathrm{X}$ ' on ' $\mathrm{Y}$ ' is statistically significantly different from 0 . And, in Equation 16.2, lags of ' $\mathrm{Y}$ ' are not causing ' $X_{t}$ '. Vector autoregressive (VAR) models are adopted to investigate the effects of government fiscal support on private $R \& D$ investment.

For the following analyses, the key dependent variable is, separately, private $R \& D$ investment, operationalised by private $R \& D$ spending, $R \& D$ labour costs and $\mathrm{R} \& \mathrm{D}$ capital investment. The independent variable is assessed as government $\mathrm{R} \& \mathrm{D}$ spending provided to business, by industry. 


\section{Findings}

The results of Granger causality are sensitive to the number of lagged years selected for analysis. Holtz-Eakin et al. (1988) suggest that the number of lagged years should be less than one-third of the total years to avoid the problem of over-identification. Given that there are 13 years in the data for each industry, this study uses no more than lagged level $\mathrm{t}-4$. The analysis begins with running VAR models with four-year lagged variables and below. Subsequently, the Akaike information criterion (AIC) and the Schwarz Bayesian Information Criterion (SBIC) were checked to find the optimal lagged years, with the results showing that lagged level $\mathrm{t}-2$ has the smallest AIC and SBIC values.

Table 16.1 illustrates models that test the correlation between government $\mathrm{R} \& \mathrm{D}$ support and total private $\mathrm{R} \& \mathrm{D}$ expenditure, including current and capital expenditure. Using the full sample, the VAR models (Models 1 and 2) fail the Granger causality test of the relationship between lagged government support $\left(\mathrm{GOV}_{\mathrm{t}-1}\right)$ and private $\mathrm{R} \& \mathrm{D}$ spending (RDEXP). The elasticity test results reveal that a 1 per cent increase in government funding in the previous year $\left(\mathrm{GOV}_{\mathrm{t}-1}\right)$ leads to a 4 per cent unit increase in private $\mathrm{R} \& \mathrm{D}$ expenditure ( $\left.\mathrm{RDEXP}_{\mathrm{t}}\right)$. On the other hand, previous government funding at $\mathrm{t}-1$ seems to induce more government funding at time $\mathrm{t}$.

When the sample is divided by the technological level of industries into high-technology industries, medium- to high-technology industries and low-technology industries (including both medium-low and lowtechnology sectors), the effects of government funding across various industries are tested by VAR models. Results from Models 3 and 4 suggest that government $\mathrm{R} \& \mathrm{D}$ support for high-technology industries is likely to be a Granger cause of private $R \& D$ spending: government financial support for $R \& D$ is positively associated with private investment in $R \& D$, consistent with the optimistic crowding-in argument of public support. The elasticity analysis reveals that a 1 per cent increase in government support is associated with a 6 per cent increase in firm-financed $R \& D$. In contrast, for medium-technology industries, VAR Models 5 and 6 fail the Granger causality test relating to public $R \& D$ assistance and private R\&D spending. For low-technology industries, in Model 7, the coefficient of $\mathrm{RDEXP}_{\mathrm{t}-1}$ is negative but insignificant. In Model 8, the privately financed R\&D expenditure in the previous year is positively associated with government spending. Taking these two models together, the Wald 
test indicates that the relationship between public $\mathrm{R} \& \mathrm{D}$ funding and private $R \& D$ spending has an inverse Granger causality: private $R \& D$ expenditure increased and then government funding for R\&D followed up. In other words, public $\mathrm{R} \& \mathrm{D}$ support for low-technology sectors is likely to have, at best, no positive effect. A grant is likely to simply allow firms in low-technology sectors to continue what they have done in terms of R\&D at a constant level (Wallsten 2000). Even worse, findings suggest that government agencies' funding decisions are heavily based on firms' previous $R \& D$ inputs. This may be because of the limited ability of the government to identify promising and capable awardees in this industry sector.

Total private $\mathrm{R} \& \mathrm{D}$ expenditure was also divided into $\mathrm{R} \& \mathrm{D}$-related labour costs and R\&D-related capital costs, with regression results presented in Tables 16.2 and 16.3, respectively. Table 16.2 demonstrates the relationship between government $\mathrm{R} \& \mathrm{D}$ support and private $\mathrm{R} \& \mathrm{D}$ related labour costs, while Table 16.3 shows the relationship between government support and private R\&D spending on capital costs. Using the whole industry sample, the models again fail the Granger causality test between government spending and private $R \& D$ costs (see Models 1 and 2). But, for high-technology industries, the Granger causality test indicates that government funding does induce private enterprises to invest more in R\&D-related activities in terms of both labour costs and capital costs (see Models 3 and 4 in Tables 16.2 and 16.3). However, for medium- to high-technology and low-technology sectors, the story is quite different. Models 5 and 6 in Table 16.2 show that, for medium- to hightechnology industries, public funding has no impact on private R\&Drelated labour costs. The results of Models 5 and 6 in Table 16.3, however, reveal the existence of an inverse Granger causality between government $\mathrm{R} \& \mathrm{D}$ assistance and private $\mathrm{R} \& \mathrm{D}$-related capital costs for medium- to high-technology industries. Similarly, Models 7 and 8 in Tables 16.2 and 16.3 show again that inverse Granger causality relationships are found between public funding and private R\&D-related labour costs and capital investment within the low-technology sector, implying that the government is likely to act as a risk-adverse investor. The findings for medium-high and low-technology industries support our conjecture that government funding is perhaps just the icing on the cake: the government supports and assists those firms that are already successful and does not focus on small, promising firms that actually need public funding to grow. 
VALUE FOR MONEY

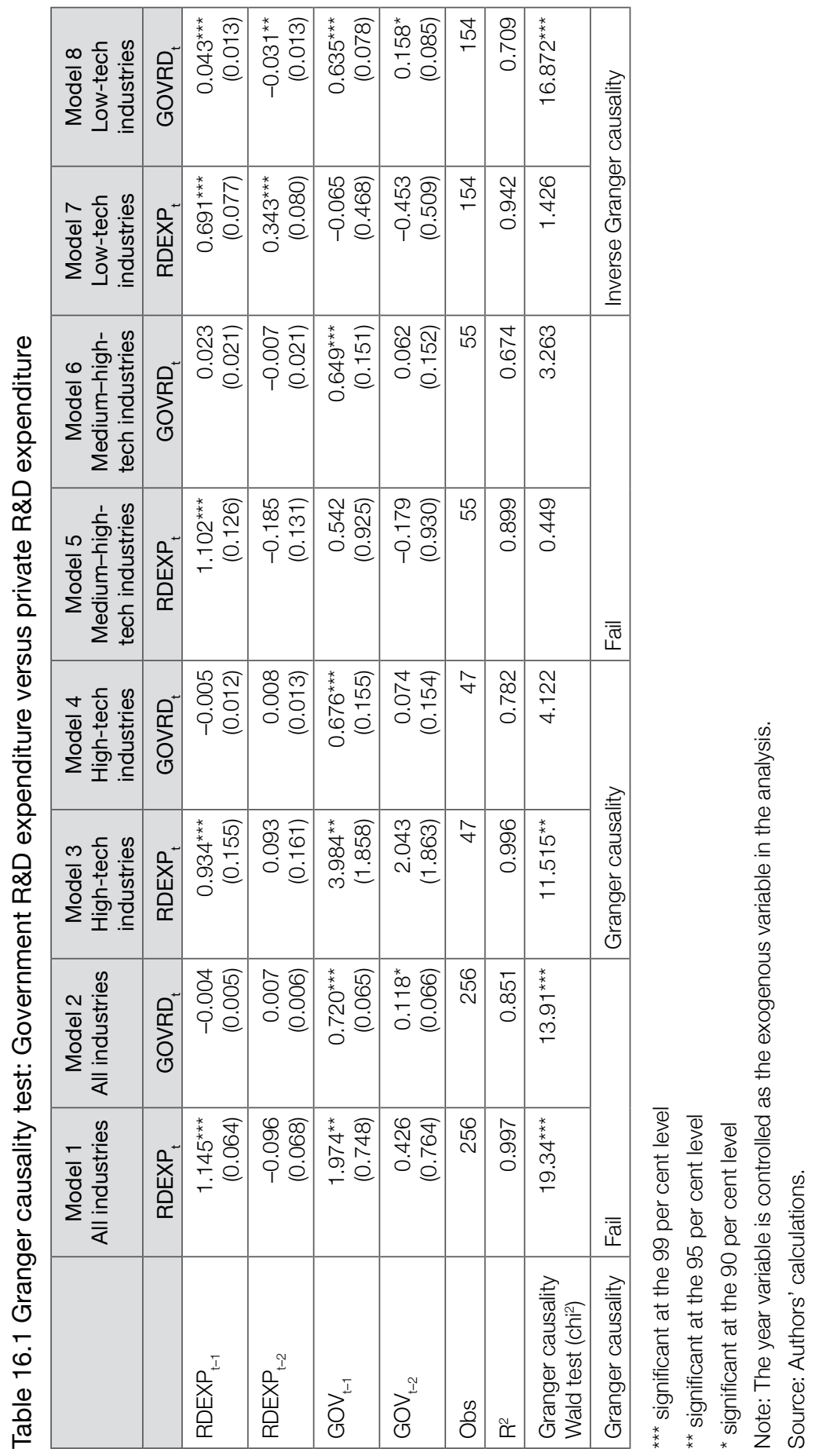


16. PUBLIC SUBSIDIES AND PRIVATE R\&D INVESTMENT IN TAIWAN

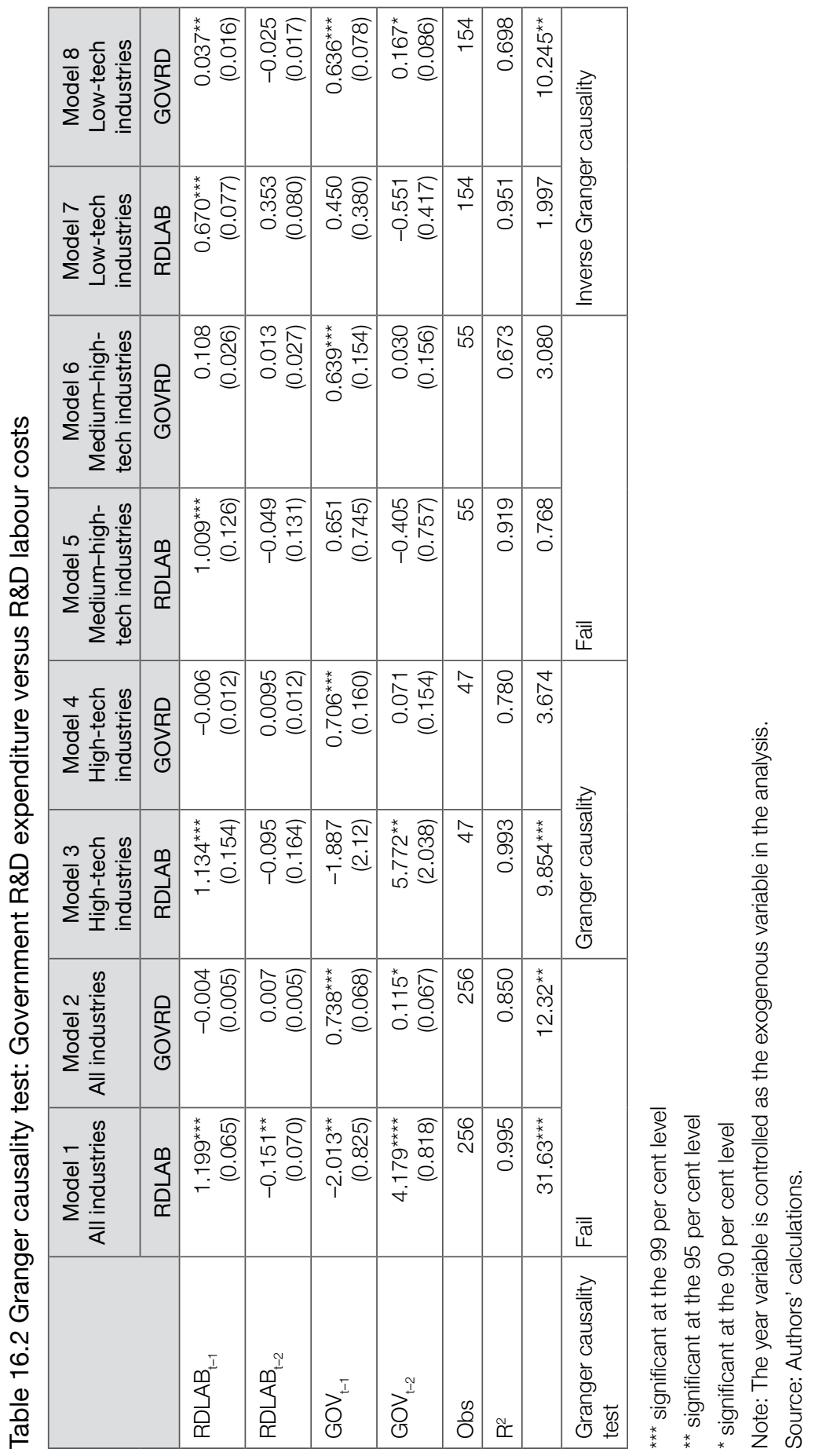


VALUE FOR MONEY

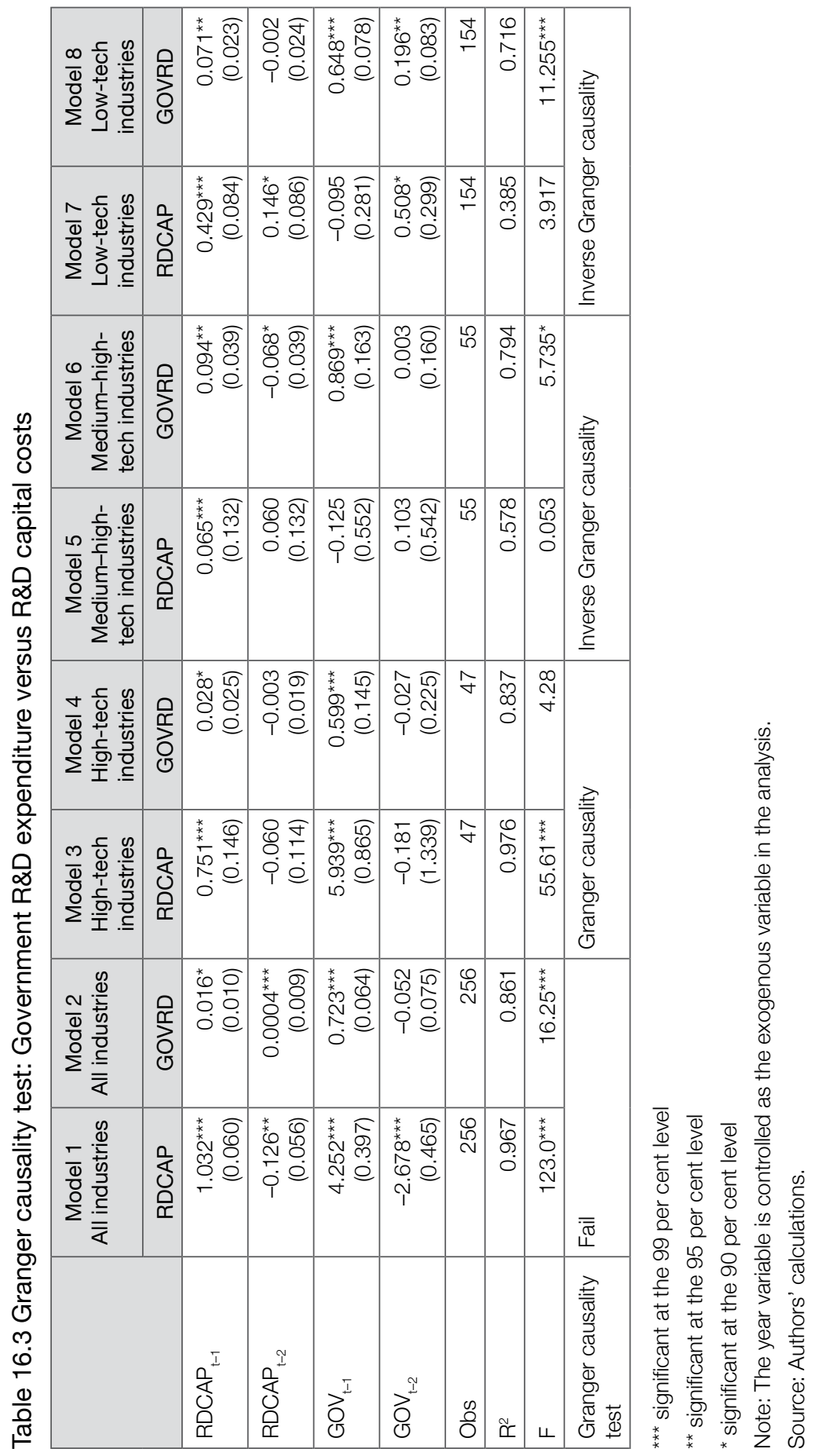




\section{Concluding remarks}

In 2009, the Taiwanese Government appropriately switched its emphasis in $\mathrm{R} \& \mathrm{D}$ support away from tax expenditure to direct subsidies, responding to evidence of the limited effectiveness of tax expenditure. The research here suggests there is a strong case for a more differentiated approach to the allocation of direct $\mathrm{R} \& \mathrm{D}$ subsidies to improve effectiveness and value for money.

Our findings suggest that industries are not risk neutral: sectors with different levels of technological intensity respond differently to public R\&D support. Government subsidies are found to induce increased private $\mathrm{R} \& \mathrm{D}$ investment in high-technology sectors, corresponding to some of the current literature, which suggests an 'additionality' effect of public spending on private R\&D. Nevertheless, there is not enough evidence to support the same effect for medium- to high-technology industries; no effect between public support and private $R \& D$ expenditure was found in the empirical model. For low-technology sectors, the relationship between our two major variables is reversed, implying that the government might be failing to make good judgments about what are risky but worthwhile $R \& D$ projects in which it should invest.

Many observers suspect the government's process for selecting who receives public $\mathrm{R} \& \mathrm{D}$ subsidies is not as robust as people expect. Blanes and Busom (2004) note that public funding is more likely to go to those firms that already conduct a lot of $R \& D$ or have had successful experience in the past. In the low-tech sectors, consistent with Bozeman and Link's (1985) suspicion about the actual use of public support, many firms may be using government funding merely to upgrade manufacturing automation, rather than conducting $\mathrm{R} \& \mathrm{D}$ projects. Findings of an inverse Granger causality between public funding and private investment in labour costs and R\&D-related capital indicate risk-adverse behaviour by the government in reviewing applications from low-tech sectors.

We also find evidence that direct public support is a Granger cause of increased private investment in $\mathrm{R} \& \mathrm{D}$ labour and $\mathrm{R} \& \mathrm{D}$-related capital investment in high-technology sectors. For medium- to high-technology sectors, such as electrical machinery and chemicals, government support does not affect decisions about private $R \& D$ investment, suggesting a deeper reluctance to undertake risky $R \& D$ or introduce new technologies even with the assistance of public funding in those manufacturing-oriented 
industries. In particular, the findings not only suggest a crowding-out phenomenon in medium- to high-tech and low-tech sectors, but also the inverse Granger relationship between public funding and private R\&Drelated capital costs implies that the government tends to offer financial support to those industries that performed well in the past, consistent with Wallsten's (2000) concern.

To summarise, we argue that government $\mathrm{R} \& \mathrm{D}$ support is likely merely to provide the icing on the cake, especially for medium- to high-technology and low-technology sectors. To maximise value for money, the Taiwanese Government needs to pay more attention to the allocation of public funds to private $\mathrm{R} \& \mathrm{D}$. As suggested above, the funds should not be a reward to those industries that have already performed well, but should be designed as an incentive for industries with $\mathrm{R} \& \mathrm{D}$ potential to invest more. Therefore, a proper review mechanism is needed to monitor and evaluate the effectiveness of the public funding of private $R \& D$. The SBIR program in the United States is an example. It has decentralised so that 11 federal agencies-including the Department of Defence and the Department of Energy-each administer their own programs based on general guidelines approved by the US Congress. In Taiwan, the Ministry of Economic Affairs is the major agency in charge of the distribution of all SBIR funds. The disadvantage of having one centralised agency is that the Ministry might not have enough expertise in the selection of the right investment targets for every sector. If this program was designated to different agencies, they could each accept proposals based on their professional judgment in line with their agency's specialty.

Finally, in shedding some light on the efficacy of government endorsement of private $\mathrm{R} \& \mathrm{D}$, the findings in this chapter have important policy implications for the government in shaping Taiwan's national and regional innovation programs. Accordingly, $\mathrm{R} \& \mathrm{D}$ subsidies can be expected to have very diverse effects on private $R \& D$ investment and on productivity across industries. The lesson learned from our empirical findings is that we are more aware of the need for an effective approach to distribute the direct subsidies that will ultimately increase the value of government money. 


\section{References}

Almus, M. and D. Czarnitzki. 2003. 'The effects of public R\&D subsidies on firms' innovation activities: The case of Eastern Germany'. Journal of Business \& Economic Statistics 21(2): 226-36. doi.org/ 10.1198/073500103288618918.

Arora, A. and W. M. Cohen. 2015. 'Public support for technical advance: The role of firm size'. Industrial and Corporate Change 24(4): 791-802. doi.org/10.1093/icc/dtv028.

Arrow, K. 1962. 'Economic welfare and the allocation of resources for invention'. In K. Arrow The Rate and Direction of Inventive Activity: Economic and social factors. Princeton Legacy Library. Princeton, NJ: Princeton University Press. Available from: ideas.repec.org/h/nbr/ nberch/2144.html (accessed 15 July 2011).

Aschhoff, B. 2009. The effect of subsidies on ReD investment and success: Do subsidy history and size matter? ZEW Discussion Paper. Mannheim, Germany: Center for European Economic Research. Available from: econpapers.repec.org/paper/zbwzewdip/09032.htm (accessed 1 February 2016).

Blanes, J. V. and I. Busom. 2004. 'Who participates in R\&D subsidy programs? The case of Spanish manufacturing firms'. Research Policy 33(10): 1459-76. doi.org/10.1016/j.respol.2004.07.006.

Bozeman, B. and A. Link. 1985. 'Public support for private R\&D: The case of the research tax credit'. Journal of Policy Analysis and Management 4(3): 370-82. doi.org/10.2307/3324191.

Brown, J. R., S. M. Fazzari and B. C. Petersen. 2009. 'Financing innovation and growth: Cash flow, external equity, and the 1990s R\&D boom'. The Journal of Finance 64(1): 151-85.

Coe, D. T. and E. Helpman. 1995. 'International R\&D spillovers'. European Economic Review 39(5): 859-87. doi.org/10.1016/00142921(94)00100-E. 
Czarnitzki, D. and A. Fier. 2002. Do innovation subsidies crowd out private investment? Evidence from the German service sector. ZEW Discussion Paper. Mannheim, Germany: Center for European Economic Research. Available from: ideas.repec.org/p/zbw/zewdip/893.html (accessed 1 February 2016).

David, P. A., B. H. Hall and A. A. Toole. 2000. 'Is public R\&D a complement or substitute for private R\&D? A review of the econometric evidence'. Research Policy 29(4-5): 497-529. doi.org/ 10.1016/S0048-7333(99)00087-6.

Department of Statistics. Various years. Yearbook of Financial Statistics. Taipei: Ministry of Finance.

Girma, S., H. Görg, E. Strobl and F. Walsh. 2008. 'Creating jobs through public subsidies: An empirical analysis'. Labour Economics 15(6): 1179-99.

González, X. and C. Pazó. 2008. 'Do public subsidies stimulate private R\&D spending?' Research Policy 37(3): 371-89. doi.org/10.1016/j. respol.2007.10.009.

Görg, H. and E. Strobl. 2007. 'The effect of R\&D subsidies on private R\&D'. Economica 74(294): 215-34. doi.org/10.1111/j.1468-0335. 2006.00547.x.

Granger, C. W. J. 1988. 'Some recent developments in a concept of causality'. Journal of Econometrics 39(1-2): 199-211.

Hall, B. H. 1992. Investment and research and development at the firm level: Does the source of financing matter? NBER Working Paper No. 4096. Cambridge, MA: National Bureau of Economic Research. Available from: www.nber.org/papers/w4096 (accessed 13 November 2015). doi.org/10.3386/w4096.

Hall, B. and J. Van Reenen. 2000. 'How effective are fiscal incentives for R\&D? A review of the evidence'. Research Policy 29(4-5): 449-69. doi.org/10.1016/S0048-7333(99)00085-2.

Hao, K. Y. and A. B. Jaffe. 1993. 'Effect of liquidity on firms' R\&D spending'. Economics of Innovation and New Technology 2(4): 275-82.

Holtz-Eakin, D., W. Newey and H. S. Rosen. 1988. 'Estimating vector autoregressions with panel data'. Econometrica 56(6): 1371-95. 
Lach, S. 2002. 'Do R\&D subsidies stimulate or displace private $\mathrm{R} \& \mathrm{D}$ ? Evidence from Israel'. The Journal of Industrial Economics 50(4): 369-90. doi.org/10.1111/1467-6451.00182.

Lerner, J. 1999. 'The government as venture capitalist: The long-run impact of the SBIR program'. The Journal of Business 72(3): 285-318.

Lerner, J. and B. H. Hall. 2010. 'The financing of R\&D and innovation'. In B. H. Hall and N. Rosenberg (eds) Handbook of the Economics of Innovation. Volume 1. Amsterdam: Elsevier. Available from: www. hbs.edu/faculty/Pages/item.aspx?num=43501 (accessed 13 November 2015).

Mansfield, E. 1986. 'The R\&D tax credit and other technology policy issues'. The American Economic Review 76(2): 190-4.

Meuleman, M. and W. De Maeseneire. 2012. 'Do R\&D subsidies affect SMEs' access to external financing?' Research Policy 41(3): 580-91. doi.org/10.1016/j.respol.2012.01.001.

Ministry of Science \& Technology and Taiwan Institute of Economic Research. 2006. Indicators of Science and Technology ROC. Taipei: Ministry of Science \& Technology.

Ministry of Science \& Technology and Taiwan Institute of Economic Research. 2007. Indicators of Science and Technology ROC. Taipei: Ministry of Science \& Technology.

Ministry of Science \& Technology and Taiwan Institute of Economic Research. 2008. Indicators of Science and Technology ROC. Taipei: Ministry of Science \& Technology.

Ministry of Science \& Technology and Taiwan Institute of Economic Research. 2009. Indicators of Science and Technology ROC. Taipei: Ministry of Science \& Technology.

Ministry of Science \& Technology and Taiwan Institute of Economic Research. 2010. Indicators of Science and Technology ROC. Taipei: Ministry of Science \& Technology.

Ministry of Science \& Technology and Taiwan Institute of Economic Research. 2011. Indicators of Science and Technology ROC. Taipei: Ministry of Science \& Technology. 
Ministry of Science \& Technology and Taiwan Institute of Economic Research. 2012. Indicators of Science and Technology ROC. Taipei: Ministry of Science \& Technology.

Ministry of Science \& Technology and Taiwan Institute of Economic Research. 2013. Indicators of Science and Technology ROC. Taipei: Ministry of Science \& Technology.

Ministry of Science \& Technology and Taiwan Institute of Economic Research. 2014. Indicators of Science and Technology ROC. Taipei: Ministry of Science \& Technology.

Organisation for Economic Co-operation and Development (OECD). 2002. Frascarti Manual 2002: Proposed Standard Practice for Surveys on Research and Experimental Development. Paris: OECD Publishing.

Organisation for Economic Co-operation and Development (OECD). 2015. Frascati Manual 2015: Guidelines for collecting and reporting data on research and experimental development. Paris: OECD Publishing. Available from: www.oecd.org/sti/frascati-manual-20159789264239012-en.htm (accessed 18 July 2017).

Solow, R. M. 1957. 'Technical change and the aggregate production function'. The Review of Economics and Statistics 39(3): 312-20.

Stock, J. H. and M. Watson. 2011. Introduction to Econometrics: International edition. 3rd edn. Boston: Pearson Education.

Toivanen, O. and P. Niininen. 2000. Investment, ReD, subsidies and credit constraints. HSEBA Working Paper No. W-264. Helsinki: Helsinki School of Economics and Business Administration, Aalto University.

Wallsten, S. J. 2000. 'The effects of government-industry R\&D programs on private R\&D: The case of the Small Business Innovation Research program'. The RAND Journal of Economics 31(1): 82-100. doi.org/ $10.2307 / 2601030$.

Yang, C.-H., C.-H. Huang and T. C.-T. Hou. 2012. 'Tax incentives and R\&D activity: Firm-level evidence from Taiwan'. Research Policy 41(9): 1578-88. doi.org/10.1016/j.respol.2012.04.006.

Zúñiga-Vicente, J. Á., C. Alonso-Borrego, F. J. Forcadell and J. I. Galán. 2014. 'Assessing the effect of public subsidies on firm R\&D investment: A survey'. Journal of Economic Surveys 28(1): 36-67. doi.org/10.1111/ j.1467-6419.2012.00738.x. 
This text is taken from Value for Money: Budget and financial management reform in the People's Republic of China, Taiwan and Australia, edited by Andrew Podger, Tsai-tsu Su, John Wanna, Hon S. Chan and Meili Niu, published 2018 by ANU Press, The Australian National University, Canberra, Australia. 